\title{
Stress response of two coral species in the Kavaratti Atoll of the Lakshadweep Archipelago, India.
}

\author{
Shashank Harithsa, Chandralata Raghukumar* and S.G. Dalal
}

Biological Oceanography Division, National Institute of Oceanography, Dona Paula, Goa 403 004, India. Fax: 91-832-2450602

\begin{abstract}
Frequent occurrences of coral bleaching and the ensuing damage to coral reefs have generated interest in documenting stress responses that precede bleaching.. The objective of this study was to assess and compare physiological changes in healthy, semi-bleached and totally bleached colonies of two coral species, Porites lutea and Acropora formosa during a natural bleaching event in the Lakshadweep Archipelago in the Arabian Sea to determine the traits that will be useful in diagnosis of coral health. In April, 2002, three "health conditions" were observed as "appearing healthy", "semi-bleached" and "bleached" specimens for two dominant and co-occurring coral species in these islands. Changes in the pigment composition, zooxanthellae density, mitotic index of zooxanthellae, RNA/DNA ratios and protein profile in the two coral species showing different levels of bleaching in the field were compared to address the hypothesis of no difference in health condition between species and bleaching status.

The loss in chlorophyll $\underline{a}$ and chlorophyll $\underline{\mathrm{c}}$ and zooxanthellae density in the transitional stage of semi-bleaching in the branched coral $A$. formosa was 80,75 and $80 \%$ respectively. The losses were much less in the massive coral $P$. lutea, being 20,50 and $25 \%$ respectively. The decrease in zooxanthellar density and chlorophyll a was accompanied by an increased mitotic index of zooxanthellae and RNA/DNA ratios in both the species. There was an increase in accumulation of lipofuscin granules in partially bleached $P$. lutea tissue, which is an indication of cellular senescence. Multivariate statistical analyses showed that colonies of $P$. lutea ranked in different health conditions differed significantly in $\mathrm{chl} \underline{\mathrm{a}}, \mathrm{chl} \underline{\mathrm{c}}$, zooxanthellae density, RNA/DNA ratios and protein concentrations whereas in $A$. formosa chl a, chl $\underline{\mathrm{c}, \mathrm{chl}} \underline{\mathrm{a} / \mathrm{c}}$, phaeopigments and mitotic index contributed to the variance between health conditions.
\end{abstract}

Keywords Lakshadweep Islands, Porites lutea, Acropora formosa, bleaching, zooxanthellae density, mitotic index, lipofuscin granules

*Corresponding author: lata@darya.nio.org 


\section{Introduction}

Coral bleaching is by far the most damaging event in coral reefs. It results in either cessation or reduction of growth and a decrease in reproductive output (Goreau and MacFarlane 1990). Concerted global efforts have been launched to monitor health of corals and especially coral bleaching events. Bleaching takes place as a response to a variety of stressors such as low and high temperatures, lower salinity, UV radiation, solar radiation and a host of chemical stressors (Kinzie et al. 2001).

Bleaching is the final manifestation of stress-related disorder in corals. Various approaches have been employed to understand bleaching, its cause and associated changes occurring in corals. The stress situation preceding bleaching may result in a decrease in the number of zooxanthellae or a decrease in photosynthetic pigments in the symbionts or both. More recently, Edmunds et al. (2003) compared zooxanthellae density and chlorophyll a content as measures of bleaching and glycerol, free amino acids, protein and mycosporine-like-amino acids collectively as tissue composition in Montastraea franski during a natural bleaching event in 1997 and 1998. Their results indicated that zooxanthellae were more sensitive to stress than coral tissue. Brown et al. (1995) have carried out studies on the physiological conditions of corals during stages preceding total bleaching. These studies addressed changes in zooxanthellae densities and histological studies in six species of corals. Le Tissier and Brown (1996) studied changes occurring during bleaching process induced by solar radiation in Goniastrea aspera in Thailand, where discrete areas of bleached tissue formed on the surface of corals among normally pigmented tissues. The bleached areas in such a situation were seen to be oriented to the sun's altitude and azimuth at the time of formation. These studies were based on chlorophyll concentrations and zooxanthellar densities. Zooxanthellae are reported to undergo rapid division in corals under stress and therefore the number of zooxanthellae appearing as doublets (the Mitotic Index of zooxanthellae) is used for assessing stress in corals (Wilkerson et al. 1988). 
Stressed coral may also experience damage in "non-pigment" components such as stress proteins (Black et al. 1995), ATP (Fang et al. 1987) and coral lipids (Harriott 1993). The concentrations of DNA remains relatively constant in a species while levels of RNA change depending upon the metabolic activity of the cell. As RNA is an essential component of protein synthesis, its concentration in tissue often reflects the rate of protein synthesis. The RNA:DNA ratio provides an index of capacity of animal to synthesize protein. Thus, healthy tissues are expected to have higher levels of RNA:DNA ratios than stressed ones (Meesters et al. 2002). Corals under stress respond by producing stress proteins, also called heat shock proteins. These are used as biomarkers to monitor environmental stress in corals (Weins et al. 2000). The increased production of stress proteins may also change the RNA/DNA ratios in stressed corals. Berkelmanns and Willis (1999) used visual estimates of the degree of bleaching as the variable for measuring the response of corals to experimental temperature manipulations. The response was measured in terms of bleaching as a single parameter.

The above listed parameters have been assayed individually under different stress conditions in various species of corals from different geographical localities. It is important to simultaneously study several such responses occurring in corals showing different levels of bleaching, the severity of such responses and their variation in different species of corals, if early detection signals are to be developed in future for preventive measures. Our study aims to contribute to this objective.

Corals of Kavaratti atoll of the Lakshadweep Archipelago in the Arabian Sea experienced unusually high temperatures (in the range of $31^{\circ}$ to $32^{\circ} \mathrm{C}$ ) in the months of April-May 2002 (Anonymous 2002). The seawater temperature throughtout the rest of the year has a monthly mean of 28 to $29^{\circ} \mathrm{C}$. In April of 2002, we noticed semi-bleached and totally bleached colonies among healthy colonies of Porites lutea and Acropora formosa occurring at about 1-3 m depth in the lagoon, near the outer reef. The various stages of bleaching among these 
two coral apecies presented the opportunity to compare these natural bleaching stages or health conditions in the two most dominant species. The healthy colonies of these two species of corals were recognizable by a normal brown color whereas the semi-bleached colonies were distinctly paler as assigned by eye (with about $30-40 \%$ color loss) and thus could be differentiated from totally bleached colonies (white). We have compared physiological response of these two species of corals in different health conditions using several parameters with a view to decide the traits which will be most useful in diagnosis of coral health.

\section{Materials and Methods}

\section{Collection of samples}

Coral samples were collected at a depth of about 1-3 m from the lagoon of the Kavaratti atoll of the Lakshadweep archipelago off the southwest coast of India (area boundaries are $10^{\circ} 32^{\prime}$ to $10^{\circ} 35^{\prime} \mathrm{N}$, and $72^{\circ} 37^{\prime}$ to $72^{\circ} 39^{\prime} \mathrm{E}$ ) in the Arabian Sea (Fig. 1). Sampling occurred on April 15, 2002.A major bleaching of corals in the sampling location was later reported in June 2002. Healthy, semibleached and bleached corals belonging to Porites lutea and Acropora formosa were collected, The two species of corals were kept submerged separately in seawater containers until processing Pigment analyses were performed immediately from these coral samples. Samples for analysis of zooxanthellae density, mitotic index and histology were fixed in $4 \%$ formalin in seawater and samples for the analysis of RNA/DNA ratio and proteins were frozen immediately in liquid nitrogen and stored at $-20^{\circ} \mathrm{C}$.

\section{Pigment analyses}

Coral tissues were stripped from the skeleton with a nylon brush into $10 \mathrm{ml}$ of $90 \%$ cold acetone. Five replicate tissue samples each from 3 individual colonies of one health condition were extracted for chlorophyll estimation. Concentrations of chlorophyll $\underline{\mathrm{a}}, \mathrm{c}_{1}+\mathrm{c}_{2}$ and phaeopigments were measured and calculated following the method of Jeffrey and Humphery (1975) and Lorenzen (1967) in a 
spectrophotometer (Perkin Elmer Lambda 60 UV/VIS, bandwidth $2 \mathrm{~nm}$ ). Coral surface area was measured on a graph paper and the pigment values are expressed per unit surface area.

Zooxanthellae density and Mitotic index

Samples were fixed in $4 \%$ formalin prepared in seawater for $24 \mathrm{~h}$ followed by fixation in $10 \%$ formalin prepared in seawater for $48 \mathrm{~h}$. The fixed samples were rinsed with tap water and were stored in $70 \%$ ethanol till further processing.

To study the zooxanthellae density (ZD), the coral pieces were removed from $70 \%$ ethanol and the surface area was determined using graph paper. These pieces were further decalcified in $1: 1$ mixture of $20 \%$ citric acid and $50 \%$ formic acid (Ravindran et al. 2001). Decalcification was carried out for about $3 \mathrm{~h}$ or till there was complete dissolution of skeleton. The coral tissue thus obtained was homogenized in filter-sterilized seawater and filtered through $60 \mu \mathrm{m}$ mesh plankton net to retain animal tissue and skeletal debris and the filtrate was centrifuged at 4,000 rpm for $10 \mathrm{~min}$. The pellet was resuspended in filtersterilized seawater and used for counting zooxanthellae density. Zooxanthellae from 3-5 subsamples each from three individual corals were counted microscopically on Neubauer Haemocytometer slide and counts were normalized to coral surface area. Mitotic index (MI) per 1000 cells for each sample was also counted (Wilkerson et al. 1988) as doublets of zooxanthellae cells.

\section{RNA/DNA ratio}

Tissues from frozen coral pieces (5 pieces each of $\mathrm{cm}^{2}$ from three conditions of health) were homogenized in $100 \mu$ lysis buffer (50 mM Tris buffer at pH 7.2 containing $50 \mathrm{mM}$ EDTA and $3 \%$ SDS). Nucleic acids were extracted and estimated following the method of Lemmens (1995). To $100 \mu \mathrm{l}$ of the sample taken in a $3 \mathrm{ml}$ cuvette, $3 \mathrm{ml}$ of bis-benzamide (BBZ-solution containing $0.1 \mathrm{mg}$ bis-benzemide $\mathrm{I}^{-1}$ in $0.05 \mathrm{M}^{\mathrm{M}}$ Tris buffer, $\mathrm{pH}$ 9.0) or ethidium bromide (EB-solution containing $10 \mathrm{mg}$ ethidium bromide $\mathrm{I}^{-1}$ in $0.05 \mathrm{M}$ Tris buffer, pH 9.0) was added. 
Fluorescence of the sample containing BBZ was read at excitation wavelength of $365 \mathrm{~nm}$ and emission wavelength of $590 \mathrm{~nm}$ for estimation of RNA. Samples containing EB were read at excitation wavelength of $352 \mathrm{~nm}$ and emission wavelength of $448 \mathrm{~nm}$ for estimation of DNA. The nucleic acids were measured as $\mu \mathrm{g}$ per unit area and their ratios were calculated. Calf thymus DNA (Sigma Chemicals, USA) and yeast RNA (HIMEDIA, India) were used as the standards.

\section{Protein profiles}

Tissue from frozen samples (6 pieces each of $\mathrm{cm}^{2}$ from three conditions of health) were homogenized using pre-chilled mortar and pestle in a mixture of phosphate buffered saline $\left(8.0 \mathrm{~g} \mathrm{NaCl}, 0.2 \mathrm{~g} \mathrm{KCl}, 0.2 \mathrm{~g} \mathrm{KH}_{2} \mathrm{PO}_{4}\right.$ and $1.15 \mathrm{~g}$ $\mathrm{Na}_{2} \mathrm{HPO}_{4} \mathrm{I}^{-1}$ of distilled water, $\mathrm{pH}$ 7.0) with protease inhibitor cocktail containing 4-(2-aminoethyl)benzene sulfonyl fluoride, E-64, bestatin, leupeptin, aprotinin and sodium EDTA, (1 $\mathrm{ml}$ inhibits protease equivalent to $1 \mathrm{mg}$ of USP pancreatin) and trypsin inhibitor Type I-S from Soybean (both from Sigma Chemicals, USA). The resulting mixture was centrifuged at $10,000 \mathrm{rpm}$ for $10 \mathrm{~min}$ at $5^{\circ} \mathrm{C}$ and the supernatant obtained was analyzed for protein concentration following the method of Lowry et al. (1951). Equal concentration of protein for all the samples was used to run sodium dodecyl sulfate-polyacrylamide gel electrophoresis (SDS-PAGE containing $6 \%$ stacking and $15 \%$ resolving gel) in a vertical gel electrophoresis unit (BioRad, USA). Broad range protein markers ranging in molecular weight from $3 \mathrm{kDa}$ to $205 \mathrm{kDa}$ containing insulin, aprotinin, lysozyme, soyabean trypsin inhibitor, carbonic anhydrase, ovalubumin, bovine serum albumin, phosphorylase $b$ and myosin of 3, 6.5, 14.3, 29, 43, 66, 97.4, $205 \mathrm{kDa}$ respectively, (Bangalore Genei Pvt. Ltd., India) were used.

\section{Histology}

Coral samples fixed in $10 \%$ formalin in seawater were decalcified in 1:1 mixture of $20 \%$ citric acid and $50 \%$ formalin till complete dissolution of skeleton. After decalcification, the animal tissue was dehydrated in a graded series of ethanol and embedded in paraffin wax and sectioned (Peters 2001). Sections of $6 \mu \mathrm{m}$ 
thickness were stained with hematoxylin and eosin and were viewed under $40 \mathrm{X}$ objective and photographed in Olympus BX 60 microscope (Tokyo, Japan) with camera attachment. The sections were also checked for the presence of lipofuscin granules (Sheehy et al. 1996). The sections $(6 \mu \mathrm{m})$ were de- waxed, mounted in DPX and covered with cover glass. Lipofuscin granules in the sections were determined by the presence of orange auto fluorescence in an Olympus BX 60 epifluorescence microscope (Tokyo, Japan) using green excitation filter and were photographed. Lipofuscin granules were stained in the coral sections using dual stain of Rhodamine B and Sudan Black B. Deparaffinized sections were stained with Rhodamine B $(0.5 \mathrm{~g}$ in $100 \mathrm{ml}$ distilled water and filtered through $0.45 \mu \mathrm{m}$ filter) for 5 min (Romeis 1989) and washed with Hedon-Fleig saline $\left(\mathrm{NaCl} 7.0 \mathrm{~g}, \mathrm{KCl} 0.3 \mathrm{~g}, \mathrm{CaCl}_{2} 0.1 \mathrm{~g}, \mathrm{NaCO}_{3} 1.5 \mathrm{~g}\right.$ and $\mathrm{MgSO}_{4} 0.3 \mathrm{~g}$ ). Sections were incubated in Sudan Black B (saturated solution in $70 \%$ ethanol) overnight at room temperature. The sections were then rinsed and differentiated in $70 \%$ ethanol till the background was pale gray, washed with tap water and viewed and photographed under 40X objective using an Olympus BX 60 epifluorescence microscope (Tokyo, Japan).

\section{Data analyses}

Prior to the analysis, each variable was tested for homogeneity of variances by comparing means and variances. After ascertaining the normality of data for all variables, we performed Principal Component Analysis (PCA) using covariance matrix of eight variables pooled for the three health conditions in each species. This was done to identify a set of variables that was responsible for a large proportion of the total variance in the health conditions of individual species. The cluster of variables from PCA was further subjected to multivariate analyses of variance (MANOVA) to determine contribution of variance by the individual parameters to the total variance. The null hypothesis of no variation in different stages of health was tested for each species and between species by means of one way ANOVA using General Linear Model (GLM). In place of ANOVA, GLM is 
preferred due to the nature of the model (unbalanced). All statistical analyses were carried out using Minitab version 8.3 (Minitab, 1991).

\section{Results}

The scleractinian corals Porites lutea is a massive coral species with polyps of 1 to $1.5 \pm 0.3 \mathrm{~mm}$ in diameter whereas, Acropora fomosa is a branched coral with larger polyps ( 1.5 to $2.5 \pm 0.25 \mathrm{~mm}$ diameter). These are found throughout the lagoon at a depth of 1-3 m.

\section{Pigment analyses}

Chlorophyll $\underline{a}$ (chl $\underline{a})$ and $\mathrm{chl} \underline{\mathrm{c}}$ concentrations in healthy Porites lutea were higher than in Acropora formosa (Fig. 2a \& 2b). The concentrations of chl a decreased by $20 \%$ and $70 \%$ in semi-bleached and totally bleached colonies of P.lutea and $70 \%$ and $90 \%$ respectively in A. formosa (Fig. 3). Likewise, significant reduction in chl $\underline{\mathrm{c}}$ concentrations in semi-bleached colonies and totally bleached colonies of P.lutea (50 and 80\%) and A.formosa (60 and 90\%) were observed (Fig. 3). Chlorophyll $\underline{a}$ to $\mathrm{chl} \underline{\mathrm{c}}$ ratios increased in bleached colonies of $P$. lutea (Fig. $2 \mathrm{c}$,) whereas they remained almost unaltered in different health conditions of $A$. formosa. Phaeopigment concentrations showed a slight increase in semibleached colonies of P.lutea (Fig. 2d). Concentrations of phaeopigments were in general much lower in $A$. formosa in all the stages of health and were of negligible concentrations in totally bleached colonies (Fig. 2d).

The initial assumption that the two species of corals differ in their response was verified by analyzing the statistical significance between two species of corals for individual parameters in one health condition (Table 1). The results of these analyses showed that zooxanthellae density, mitotic index, nucleic acid ratio and protein content did not show statistically significant variation between healthy $P$. lutea and $A$. formosa. In semi-bleached corals mitotic index and RNA/DNA ratios were not significantly different between the 
two species. In totally bleached corals $\mathrm{chl} \underline{\mathrm{c}}$ and nucleic acid ratios did not show variations between the two species of corals (Table 1).

Zooxanthellae density and mitotic index showed statistically significant difference in the three stages of health in both the species of corals (Table 2). However, between the two species of healthy-looking corals the difference was not significant (Table 1). Zooxanthellae density decreased by $20 \%$ in semibleached P.lutea colonies but drastically $(70 \%)$ in totally bleached colonies (Fig. $2 e$ and Fig. 3). On the other hand, this decrease in A. formosa was about 75 and $90 \%$ in semi- and totally bleached colonies respectively (Figs. 2e and 3). Number of doublets of zooxanthellae, which is expressed as mitotic index (MI) increased in semi-bleached colonies of both the species of corals (Fig. 2f). In totally bleached colonies of $P$. lutea, $\mathrm{Ml}$ was much lower than healthy tissue and was undetectable in A. formosa (Fig. 2f). The was no inter-species statistical variation in the mitotic index of zooxanthellae in healthy and semi-bleached colonies (Table 1).

The RNA/DNA ratio in semi-bleached colonies showed increase over healthy in both the species of corals (Fig. $2 \mathrm{~g}$ ). This ratio was significant between three stages of health in individual species of corals (Table 2) but not when each health condition was compared between two species (Table 1). The total protein concentrations increased in the totally bleached colonies of both the coral species but not in the semi-bleached ones (Fig. 2h). This parameter was statistically significant in three stages of health in $P$. lutea only (Table 2).

Principal Component Analysis (PCA) of all the variables pooled for the three health conditions of each species of coral showed that chl $\underline{a}$ and $\mathrm{chl} \underline{\mathrm{c}}$ contributed (Fig 4a \& 4b) significantly to the difference in health conditions in both the species. However, in P.lutea, zooxanthellae density also added to this significance. In A. Formosa, chl a/chl c ratio_contributed to this significance (Fig. 4). PCA generated Factor 1 and Factor 2 that described $52 \%$ and $19 \%$ of the variance respectively in $P$. lutea (Table 3 ). Factor 1 was characterized by high 
positive component loadings for $\mathrm{chl} \underline{\mathrm{a}}$, chl $\underline{\mathrm{c}}$, zooxanthellae density, and RNA/DNA ratio and a negative component loading for mitotic index in $P$. lutea. Factor 2 was characterized by high positive loading for protein in this species (Table 3).

For A.formosa, Factor 1 and Factor 2 described 54 and $16 \%$ of the variance. Factor 1 was characterized by high positive component loadings for chl $\underline{\mathrm{a}}$, chl $\underline{\mathrm{c}}$, chl a/chl c ratio, and phaeopigments concentrations; Factor 2 was characterized by high positive loading for mitotic index (Table 3). In summary, chl a and chl c were the large positive loading factors common to both the species of the corals (Table 3 ). Protein concentration in P. lutea and mitotic index in $A$. formosa contributed only $19 \%$ and $16 \%$ of the variance respectively out of the total $70 \%$ and $71 \%$ variance in these two corals (Table 3 ). Multivariate analysis of variance (MANOVA) of the most important principal components (Factor 1) showed that $P$. lutea samples assigned to three health conditions differed significantly in chl a, chl c, zooxanthellae density, RNA/DNA ratios and protein concentrations (MANOVA: Wilk's $\lambda=0.004, \mathrm{~F}=22.28, \mathrm{df}=10,16, \mathrm{P}=<0.00$ ) and the different health conditions of A.formosa differed significantly in chl a, chl c, chl $\mathrm{a} / \mathrm{c}$, phaeopigment concentrations and mitotic index (MANOVA: Wilk's $\lambda=0.022$, $F=37.04, d f=10,66, P=<0.00)$.

Electrophoresis of protein using SDS-PAGE showed a differential expression of proteins in semi-bleached and bleached tissues from that of healthy tissues (Fig. 5a \& 5b). Expression of new proteins was observed between 6.5-14.3 kDa and between 20-29 kDa in the bleached tissue of $P$. lutea (Fig. 5a). In A. formosa the new protein expression was in the range of 29-39 $\mathrm{kDa},>43$ and $<66 \mathrm{kDa}$ in the semi-bleached tissue. A protein band present between 14-20 kDa in the semi-bleached tissue was absent in the bleached tissue of this species (Fig. 5b). 


\section{Histological changes}

Increased presence of lipofuscin granules could be seen in the $P$. lutea sections of semi-bleached tissue. The lipofuscin granules could be recognized by their yellowish color when viewed under bright field (Fig. 6a) and silver white fluorescence when stained with Rhodamine B (Fig. 6b \& 6c) and appear black when counterstained with Sudan Black B (Fig. 6d). The concentration of these granules was higher in the sections of semi-bleached than in healthy and negligible in bleached sections of coral polyps. The number of lipofuscin granules in healthy and semi-bleached sections was 2495 and $3106 \mathrm{~cm}^{-2}$ respectively. The lipofuscin granules were larger in size in semi-bleached than in healthy tissue. They were not observed in the sections of $A$. formosa under any health condition.

Sections of the semi-bleached tissues of $P$. lutea showed large vacuoles in the endodermal layer indicating tissue degeneration and the bleached tissue was almost completely degraded (Fig. 7 a-c). Density of zooxanthellae in the epidermal layers of $A$. formosa varied in healthy, semi-bleached and totally bleached tissue sections. The endoderm, mesoglea and epidermis were in reduced or disintegrated state in bleached sections of $A$. formosa (Fig. 7d-f).

\section{Discussion}

Bleaching in corals is either due to loss of zooxanthellae that bear the pigments, or loss of pigments in zooxanthellae without the zooxanthellae themselves being expelled (Hoegh-Guldberg and Smith 1989; Szmant and Gassman 1990; Fitt and Warner 1995). In the latter case, chlorophyll $\underline{a}$ and chl $\underline{c}$ may decrease in stressed and diseased corals because they are degraded to form phaeopigments (Brown 1997). In P.lutea during the present study, a decrease in chl $\underline{a}$ and chl $\underline{\mathrm{c}}$ is accompanied by an increase in phaeopigments and comparatively lesser loss of zooxanthellae suggesting that the loss in chlorophyll is due to its degradation. In contrast, a significant decrease in chl a in semibleached corals of Acropora formosa is accompanied by a drastic reduction in 
zooxanthellae density (Fig. 2a and 2e). Some studies have not endorsed losses in chlorophyll $\underline{a}$ and $\underline{\mathrm{c}}$ and have even suggested an increase of these pigments in stressed and bleached corals (Szmant and Gassman 1990; Le Tissier and Brown 1996). This has been ascribed to increased nutrient availability to the remnant algae in the host or the greater loss of apical algae leaving the subsurface algae with higher chlorophyll concentrations below (Brown et al. 1999). Therefore, chlorophyll a concentrations and zooxanthellae densities may not be universally applicable as early stress indicators.

Reduction in chlorophyll $\underline{\underline{c}}$ levels were always accompanied by similar magnitude of reduction in zooxanthellae densities in both the coral species (compare Fig. 2b and 2e). Le Tissier and Brown (1996) have reported similar results during solar bleaching of Goniastrea aspera in Thialand. Reduction in chl $\underline{c}$ concentrations has also been reported during natural bleaching event in stony corals (Kleppel et al. 1989) and in experimental studies with anthozoans using increased irradiance (Lesser et al. 1990).

Zooxanthellae densities in semi-bleached corals showed a significant decrease only in Acropora formosa, but not in Porites lutea. Both the species of corals studied here showed reduction of zooxanthellae densities with advanced stages of bleaching. Reduction in zooxanthellae numbers during natural bleaching event was reported in six species of corals (Brown et al. 1995) and in solar bleached Goniastrea aspera (Le Tissier and Brown 1996). Increased seasurface temperature (SST) and photosynthetically active radiation (PAR) experienced by shallow water corals at Phuket in Thailand also showed decreased zooxanthallae numbers on an annual basis (Brown et al. 1999). In Montastraea franski the reduction in zooxanthellae correlated with scale of bleaching but this did not correlate with changes in tissue composition (Edmunds et al., 2003). In certain cases, stress on zooxanthellae may not be reflected in their densities, although their viabilities may be affected. The zooxanthellae density in healthy looking tissue of the two species did not show significant variation (Table 1). However their numbers in semi-bleached and bleached 
stages of both the species of corals varied significantly (Table 1). Therefore, this parameter alone may not be reliable for monitoring health condition of corals.

Another important parameter that has been used by various authors to analyze stress is the mitotic index (MI) of zooxanthellae. Our results indicate that $\mathrm{MI}$ of zooxanthellae remaining in the hosts (in hospite) was significantly variable in the three health conditions in both the coral species (Fig. $2 f$ Table 2). Jones (1997) did not find significant differences in Ml of cells between control and test polyps retained in the host during toxicity studies of copper on zooxanthellae in Acropora formosa, However, this difference was significant in the zooxanthellae expelled from the host. During our studies comparison between two species of coral in healthy and semi-bleached conditions showed no significant variation in MI (Table 1). Non-detection of doublets of zooxanthellae as seen the bleached colonies of $A$. formosa might be due to their expulsion from the host. This parameter, therefore, alone appears to be unreliable to assess stress.

The healthy colonies of both the species did not show significant variations in zooxanthellae density, mitotic index, nucleic acid ratios and protein concentrations (Table 1). Thus initially both the species of corals were almost similar in several respects. However, as the bleaching progressed these traits showed significant variations (Table 1). It can be concluded that the stag horn coral A.formosa on the whole showed a greater loss of chlorophyll $\underline{a}, \operatorname{chl} \underline{\mathrm{c}}$ and zooxanthellae and higher mitotic index than the massive coral species $P$. lutea (Fig. 3). Thus the former showed more pronounced stress reactions than the massive coral. These observations correspond with the higher incidence of bleaching in Acropora noticed during physical monitoring of reefs in the Lakshadweep Islands during June-July 2002, as compared to Porites spp (per. Comm. from Lakshadweep Coral Monitoring Network).

Ravindran (2002) reported higher chl a values and lower zooxanthellae density in $P$. lutea (Table 4) whereas Brown et al, (1999) reported much lower values. Similarly, Jones (1997a) reported higher than our values of chl a in $A$. 
formosa. The low values of chlorophyll $\underline{a}$ and $\underline{c}$ observed during the current study might indicate that the so-called healthy colonies were already showing signs of stress undetectable by human eye. Alternatively, chlorophyll and zooxanthellae density are highly variable on temporal and spatial scale and therefore, the threshold values for healthy corals will also change accordingly. Therefore, it is recommended to measure chlorophyll content and zooxanthellae density in 2-3 species of corals at a regular time interval to monitor coral health in reefs.

Accumulation of lipofuscin granules usually occurs when cellular integrity is challenged. These are induced in response to free radicals generated during oxidative stress (Gaugler 1997). Lipofuscin accumulation was reported in the clam Sunneta scripta and the mussel Perna viridis in response to oxidative stress (Mathew and Damodaran 1997). Age-dependent lipofuscin accumulation was reported in neurons of decapods and was even used in determining the age of European lobster Homarus gammarus (Sheehy et al. 1996). Concentrations of lipofuscin granules increased significantly in semi-bleached colonies of $P$. lutea and were negligible in fully bleached colonies. They were present in large numbers in the semi-bleached colonies and could be seen all over the sections. Long-term study of lipofuscin accumulation in species of Porites in response to stress will help to better understand the behavior of coral under stress. However, A. formosa did not show lipofuscin granules in healthy or stressed condition. Therefore, it appears that lipofuscin accumulation is not a general phenomenon in stressed corals.

There was a general degradation of endodermal tissue in semi-bleached and totally bleached tissues of both the species. As seen in earlier studies (Le Tissier and Brown 1996; Dunn et al. 2002), zooxanthellae with normal morphology were seen within endodermal cells and also in coelenteron with degraded endoderm tissue. The excretion of zooxanthellae is not always dependent on the stage of degeneration of tissues (Taylor 1968). 
It is reported that heat shock proteins or stress proteins are synthesized when coral is under stress because their expression can be induced by a number of stressful conditions (Black et al. 1995). The protein expressed in stressed corals may not be present in healthy or vice versa. Both the species in the current study exhibited the presence of extra proteins during the two stages of bleaching, and these proteins differed in terms of their molecular weight. Semibleached and bleached $P$. lutea showed the expression of small molecular weight proteins $(6.5-30 \mathrm{kDa})$, whereas, in semi-bleached and bleached $\mathrm{A}$. formosa, a wide range of new proteins were expressed viz.; 29-39 kDa and 66 kDa. Similar observations were made by Black et al. (1995) in Montastrea faveolata and in Aptasia pallida on a reef near Joulters Cay, north of Andros Island, Bahamas and by Sharp et al. (1994) in Anemonia viridis and Fang et al. (1997) in Acropora grandis from Nanwan, southern tip of Taiwan. Cervino et al. (2003) have reported similar expression and inhibition of protein in Acropora millepora exposed to cyanide. It needs to be confirmed whether the expression of new proteins seen in the present studies are heat shock proteins (hsps) as is reported in other corals.

Increase in the protein expression in semi-bleached and bleached corals is further supported by increased RNA/DNA ratios. Earlier studies on this aspect by Meesters et al. (2002) carried out on Porites spp. from islands off the northwestern coast of Java, Indonesia has dealt with effect of irradiance and turbidity gradient on RNA/DNA ratio in corals. The RNA content of tissue is related to growth rate and temperature (Wagner et al. 1998). In our study increased temperature induced increased RNA production in both the species. The expression of new stress proteins in semi-bleached and bleached tissue might be the result of this increase.

The worldwide havoc that bleaching has been causing to corals in recent years has given rise to great interest in understanding the stress reactions and developing molecular and biochemical markers as early detection signals. Recently various biochemical and molecular markers have been reported from 
different cnidarians in general and different species of corals in particular (Brown et al. 2002; Michelmore et al. 2002). Various groups of workers have emphasized on different mechanisms of stress response.

In the present study, reduction in zooxanthellae density, photosynthetic pigments, increased mitotic index, RNA:DNA ratios and the production of extra proteins appeared to be common stress responses. The principal component analysis of various factors pooled from the three different health conditions in two species of corals suggest that stress on coral can be monitored accurately to the extent of $52-54 \%$ by monitoring $\mathrm{chl} \underline{\mathrm{a}}, \mathrm{chl} \underline{\mathrm{c}}, \mathrm{chl}$ a/c, phaeopigment, zooxanthellae density, protein concentration and nucleic acid ratios. Multiple analyses of variance of the most important principal components further showed these traits contributed most significantly to the different health conditions. We are of the opinion that suites of such conventional responses in different coral species needs to be assayed in place of individual parameters at a regular time interval and such studies would help to evolve better early detection signals for coral monitoring programs. Additionally, such a comparison would help to assess the threshold values of key parameters that decide between healthy and bleached corals.

\section{Acknowledgements}

We thank Dr. Ismail Koya, Deputy Director of the Department of Science and Technology at Kavaratti for the facilities provided during this study. We also thank Dr. E. Desa, Director of our Institute for help and encouragement. The senior author $(\mathrm{SH})$ and the corresponding author (CRK) gratefully acknowledge the research fellowship and the research grant offered respectively by the Ministry of Environment and Forests (MOEF, New Delhi). We are also thankful to P. Koya, SPORTS-Lakshadweep for helping in the collection of samples and Ms. Jane Paul, NIO, for suggestions in histological techniques. We wish to thank Dr. S. Raghukumar and two anonymous referees for critical evaluation of the manuscript. This is NIO's contribution No. 3946. 


\section{References}

Anonymous (2002) Environmental Impact Assessment of Ninth Five Year Plan, 1997-2002. Department of Science, Technology and Environment, Lakshadweep pp 128.

Berkelmans R, Willis BL (1999) Seasonal and local spatial patterns in the upper thermal limits of corals on the inshore Central Great Barrier Reef. Coral Reefs 18:219-228.

Black NA, Voellmy R, Szmant AM (1995) Heat shock protein induction in Montastrea faveolata and Aiptasia pallida exposed to elevated temperatures. Biol Bull 188:234-240

Brown BE (1997) Coral bleaching: causes and consequences. Coral Reefs 16 (Suppl): S129-S138

Brown BE, Le Tissier MD, Bythell JC (1995) Mechanism of bleaching deduced from histological studies of reef corals sampled during a natural bleaching event. Mar Biol 122:655-663

Brown BE, Dunn RP, Ambarsari I, Le Tissier MDA, Satpoonin U (1999) Seasonal fluctuations in environmental factors and variations in symbiotic algae and chlorophyll pigments in four Indo-Pacific coral species. Mar Ecol Prog Ser 191:53-69

Brown BE, Downs CA, Dunne RP, Gibb SW (2002) Preliminary evidence for tissue retraction as a factor in photoprotection of corals incapable of xanthophyll cycling. J Exp Mar Biol Ecol 277:129-144

Cervino JM, Hayes RL, Honovich M, Goreau TJ, Jones S, Rubec PJ (2003) Changes in zooxanthellae density, morphology and mitotic index in hermatypic corals and anemones exposed to cyanide. Mar Poll. Bull. 46: 573-586 
Dunn SR, Bythell JC, Le Tissier MDA, Burnett WJ, Thomason JC (2002)

Programmed cell death and cell necrosis activity during hyperthermic stress-induced bleaching in the symbiotic sea anemone Aiptasia sp. J Exp Mar Biol Ecol 272:29-53

Edmunds PJ, Gates RD, Gleason DF (2003) The tissue composition of Montastaea franski during a natural bleaching event in the Florida Keys. Coral Reefs 22: 54-62

Fang L-S, Chen YWJ Chen CS (1987) Feasibility of using ATP as an index for environmental stress on hermatypic coral. Mar Ecol Prog Ser 70:257-262

Fang L-S, Huang SP, Lin KL (1997) High temperature induces the synthesis of heat shock proteins and elevation of intracellular calcium in the coral Acropora grandis. Coral Reefs 16:127-131

Fitt WK, Warner ME (1995) Bleaching patterns of four species of Caribbean reef corals. Biol Bull 189:298-307

Gaugler C (1997) Lipofuscin. wwwchem.csustan.edu/chem4400/SJBR/

Goreau TJ, MacFarlane AH (1990) Reduced growth rate of Montastrea annularis following the 1987-1988 coral bleaching event. Coral Reefs 8:211-215

Harriott VJ (1993) Coral lipids and environmental stress. Environ Monit Assess 25:131-139

Hoegh-Guldberg O, Smith GJ (1989) The effect of sudden changes in temperature, light and salinity on the population density and export of zooxanthellae from the reef corals Stylopora pistillata Esper and Seriatopora hystrix Dana. J Exp Mar Biol Ecol 129:279-303

Jeffrey SW, Humphrey GF (1975) New spectrophotometric equations for determining chlorophylls $a, b, c_{1}+c_{2}$ in higher plants, algae and natural phytoplankton. Biochem Physiol Pflanzen Bd 167:191-194 
Jones RJ (1997) Zooxanthellae loss as a bioassay for assessing stress in corals Mar Ecol Prog Ser 149:163-171

Jones RJ (1997a) Changes in zooxanthellar densities and chlorophyll concentrations in corals during and after a bleaching event. Mar Ecol Prog Ser 158: 51-59

Kinzie RA, Takayama M, Santoos SR, Coffroth MA (2001) The adaptive bleaching hypothesis:Experimental tests of critical assumptions. Biol Bull 200:51-58

Kleppel GS, Dodge RE, Reese CJ (1989) Changes in pigmentation associated with the bleaching of stony corals Limnol Oceanogr 34:1331-1335

Lesser MP, Stochaj WR, Tapley DW, Shick JM (1990) Bleaching in coral reef anthozoans: effects of irradiance, ultraviolet radiation and temperature on the activities of protective enzymes against active oxygen. Coral Reefs 8:225-232

Le Tissier MDA, Brown BE (1996) Dynamics of solar bleaching in the intertidal reef coral Goniastrea aspera at Ko Phuket, Thailand. Mar Ecol Prog Ser $136: 235-244$

Lemmens JWTJ (1995) Nucleic acid levels, cellular activity and growth during the puerulus stage of the Western Rock Lobster (Panulirus Cygnus (George); Decapoda: Palinuridae. J Exp Mar Biol Ecol 194:143-156

Lorenzen CJ (1967) Determination of Chlorophyll and Phaeo-Pigments: Spectrophotometric Equations. Limnol Oceanogr 12:343-346

Lowry OH, Rosenberg NJ, Farr A, Rendall RJ (1951) Protein measurement with the Folin-phenol reagent. J Biol Chem 193:265-275 
Mathew S, Damodaran R (1997) Effect of ambient oxygen concentration on lipofuscin accumulation in a clam Sunneta scripta and mussel Perna viridis. Ind J Mar Sci 26:57-63

Meesters EH, Nieuwland G, Duineveld GCA, Kok A, Bak RPM (2002)

RNA/DNA ratios of scleractinian corals suggest acclimatisation/adaptation in relation to light gradients and turbidity regimes. Mar Ecol Prog Ser 227: 233-239

Minitab Inc (1991) Minitab Release manual: release 8.3 for PC. State College, PA

Mitchelmore CL, Schwarz JA, Weis VM (2002) Development of symbiosisspecific genes as biomarkers for the early detection of cnidarian-algal symbiosis breakdown. Mar Environ Res 54:345-349

Peters EC (2001) Histotechnique, In Coral Tissue Slide Reading Workshop, Biology Department George Mason University pp. 116

Ravindran J, Raghukumar C, Raghukumar S (2001) Fungi in Porites lutea: association with healthy and diseased corals. Dis Aqua Org 47:219-228

Ravindran J (2002) Pathogens associated with diseased corals: a case study. $\mathrm{Ph}$. D thesis of Goa University, India

Romeis B (1989) Mikroskopische technik, 17. Neubearbeitete Auflage, Urban \& Schwarzenberg.

Sharp VA, Miller D, Bythell JC, Brown BE (1994) Expression of low molecular weight HSP 70 related polypeptides from the symbiotic anemone Anemonia viridis Forskal in response to heat shock. J Exp Mar Biol Ecol 179:179-193 
Sheehy MRJ, Shelton PMJ, Wickins JF, Belchier M, Gatess E (1996) Ageing in the European lobster Homarus gammarus by lipofuscin in its eyestalk ganglia. Mar Ecol Prog Ser 149:99-111

Szmant AM, Gassman NJ (1990) The effects of prolonged 'bleaching' on the tissue biomes and reproduction of the reef coral Montastrea annularis. Coral Reefs 8:217-224

Taylor DL (1968) In situ studies on the cytochemistry and ultrastructure of a symbiotic marine dinoflagellate. J Mar Biol Ass UK 48:348-366

Wagner M, Durbin E, Buckley L (1998) RNA:DNA ratios as indicators of nutritional condition in the copepod Calanus finmarchicus. Mar Ecol Prog Ser 162:173-181

Weins M, Ammar MSA, Nawar A, Koziol C, Hassanein HMA, Eisinger M, Muller I M, Muller WEG (2000) Induction of heat-shock (stress) protein gene expression by natural and anthropogenic disturbances in the octocoral Dendronephthya klunzingeri. J Exp Mar Biol Ecol 245:265-276

Wilkerson FP, Kobayashi D, Muscatine L (1988) Mitotic index and size of symbiotic algae in Caribbean reef corals. Coral Reefs 7:29-36 
Table 1. One- way ANOVA using General Linear Model (GLM) for comparing variations between two species of corals showing similar level of health condition.

\begin{tabular}{|c|c|c|c|}
\hline Variable & F-value & P-value & $\begin{array}{l}\text { Degree of } \\
\text { freedom }\end{array}$ \\
\hline \multicolumn{4}{|l|}{ Healthy-looking } \\
\hline Chlorophyll a & 9.63 & 0.004 & 1,38 \\
\hline Chlorophyll $\underline{\mathrm{c}}$ & 4.67 & 0.037 & 1,38 \\
\hline Phaeopigments & 6.57 & 0.014 & 1,38 \\
\hline Zooxanthellae density & 1.69 & $0.21^{*}$ & 1,18 \\
\hline Mitotic Index & 1.65 & $0.21^{*}$ & 1,18 \\
\hline RNA:DNA ratio & 3.84 & $0.086^{*}$ & 1,8 \\
\hline Protein & 0.17 & $0.69^{*}$ & 1,8 \\
\hline \multicolumn{4}{|l|}{ Semi-bleached } \\
\hline Chlorophyll a & 65.42 & 0.000 & 1,38 \\
\hline Chlorophyll $\underline{\mathrm{c}}$ & 8.43 & 0.006 & 1,34 \\
\hline Phaeopigments & 30.35 & 0.001 & 1,34 \\
\hline Zooxanthellae density & 127.52 & 0.000 & 1,18 \\
\hline Mitotic Index & 2.83 & $0.11^{*}$ & 1,18 \\
\hline RNA:DNA ratio & 0.72 & $0.42^{*}$ & 1,8 \\
\hline Protein & 65.16 & 0.000 & 1,8 \\
\hline \multicolumn{4}{|l|}{ Bleached } \\
\hline Chlorophyll $\underline{a}$ & 34.51 & 0.000 & 1,28 \\
\hline Chlorophyll $\underline{\mathrm{c}}$ & 4.2 & 0.05 & 1,28 \\
\hline Phaeopigments & 22.2 & 0.000 & 1,28 \\
\hline Zooxanthellae density & 75.51 & 0.000 & 1,18 \\
\hline Mitotic Index & 6.00 & 0.025 & 1,18 \\
\hline RNA:DNA ratio & 0.076 & $0.408^{*}$ & 1,8 \\
\hline Protein & 29.64 & 0.000 & 1,8 \\
\hline
\end{tabular}

${ }^{*}$ not significant 
Table 2. One-way ANOVA using General Linear Model (GLM) to compare variations in individual parameters between 3 stages of health in corals.

\begin{tabular}{|c|c|c|c|}
\hline Variable & F-value & P-value & $\begin{array}{l}\text { Degree of } \\
\text { freedom }\end{array}$ \\
\hline Porites lutea & & & \\
\hline Chlorophyll $\underline{a}$ & 19.4 & 0.001 & 2,43 \\
\hline Chlorophyll $\underline{\mathrm{c}}$ & 43.4 & 0.001 & 2,43 \\
\hline Chl a: chl $\underline{c}$ ratio & 5.0 & 0.01 & 2,43 \\
\hline Pheopigments & 2.7 & $0.08^{*}$ & 2,43 \\
\hline Zooxanthellae density & 310.7 & 0.001 & 2,27 \\
\hline Mitotic Index & 42.4 & 0.001 & 2,27 \\
\hline RNA:DNA ratio & 6.4 & 0.01 & 2,15 \\
\hline Protein & 4.8 & 0.03 & 2,12 \\
\hline \multicolumn{4}{|l|}{ Acropora formosa } \\
\hline Chlorophyll $\underline{\mathrm{a}}$ & 45.5 & 0.001 & 2,57 \\
\hline Chlorophyll $\underline{\mathrm{c}}$ & 84.7 & 0.001 & 2,57 \\
\hline Chl a:chl $\underline{\mathrm{c}}$ ratio & 0.04 & $0.96^{*}$ & 2,57 \\
\hline Pheopigments & 8.4 & 0.001 & 2,57 \\
\hline Zooxanthellae density & 25.5 & 0.001 & 2,27 \\
\hline Mitotic Index & 21.3 & 0.001 & 2,27 \\
\hline RNA:DNA ratio & 3.1 & 0.05 & 2,15 \\
\hline Protein & 2.2 & $0.15^{*}$ & 2,12 \\
\hline
\end{tabular}

* Not significant due to unusually low or high values in the replicate samples. 
Table 3. Principal component analysis (PCA) of the eight parameters pooled from all the three conditions of health. PCA generated two principal components; factor 1 explained 52 and $54 \%$ of the variance and factor 2 explained 19 and $16 \%$ of the variance in P.lutea and A. formosa respectively. Together they explained about 71 and $72 \%$ of the variation in these two species. Numbers in bold indicate values that contributed more than 0.7 of variance.

\begin{tabular}{|l|l|l|l|l|}
\hline & \multicolumn{2}{l}{ Porites lutea } & \multicolumn{2}{l|}{ Acropora Formosa } \\
\hline & Factor 1 & Factor 2 & Factor 1 & Factor 2 \\
\hline Eigenvalues & 4.2 & 1.5 & 4.3 & 1.3 \\
\hline Expained variance (\%) & 52.1 & 18.8 & 54.2 & 15.8 \\
\hline Component loadings & & & & \\
\hline Chl a & $\mathbf{0 . 8 5 6}$ & -0.099 & $\mathbf{0 . 9 4 2}$ & 0.257 \\
\hline Chl c & $\mathbf{0 . 9 0 3}$ & 0.359 & $\mathbf{0 . 6 6 5}$ & 0.595 \\
\hline Chl a/c & -0.536 & -0.469 & $\mathbf{0 . 9 0 0}$ & 0.081 \\
\hline Phaeopigments & 0.603 & -0.374 & $\mathbf{0 . 7 7 3}$ & 0.516 \\
\hline ZD & $\mathbf{0 . 8 7 3}$ & 0.228 & 0.397 & 0.541 \\
\hline Mitotic index & -0.696 & -0.288 & 0.114 & $\mathbf{0 . 9 2 1}$ \\
\hline RNA/DNA ratio & $\mathbf{0 . 7 6 6}$ & -0.473 & -0.668 & 0.224 \\
\hline Protein & -0.373 & $\mathbf{0 . 8 0 8}$ & -0.237 & -0.555 \\
\hline
\end{tabular}


Table 4. Comparison of chlorophyll and zooxanthellae density reported in the present study with that of other studies.

\begin{tabular}{|c|c|c|c|c|c|c|}
\hline $\begin{array}{l}\text { Coral } \\
\text { species }\end{array}$ & Reference & Year & Location & $\begin{array}{l}\text { Zooxanthellae } \\
\text { numbers } \mathrm{cm}^{-2}\end{array}$ & $\begin{array}{l}\text { pg Chl } \\
\text { a cell }\end{array}$ & $\begin{array}{l}\text { pg Chl } \\
\text { c cell }\end{array}$ \\
\hline \multirow[t]{3}{*}{ P. Iutea } & $\begin{array}{l}\text { Present } \\
\text { study }\end{array}$ & 2002 & $\begin{array}{l}\text { Kavaratti, } \\
\text { Lakshadweep } \\
\text { Islands }\end{array}$ & $\begin{array}{l}3.5 \times 10^{6} \pm \frac{ \pm}{6} \\
0.23 \times 10^{6}\end{array}$ & 3.1 & 4.7 \\
\hline & $\begin{array}{l}\text { Ravindran } \\
2002\end{array}$ & 2000 & $\begin{array}{l}\text { Kavaratti, } \\
\text { Lakshadweep } \\
\text { Islands }\end{array}$ & $\begin{array}{l}2.7 \times 10^{6} \pm \\
1.4 \times 10^{6}\end{array}$ & 5.1 & 3.8 \\
\hline & $\begin{array}{l}\text { Brown et } \\
\text { al. } 1999\end{array}$ & $\begin{array}{l}1992- \\
1996\end{array}$ & $\begin{array}{l}\text { Phuket, } \\
\text { Thailand }\end{array}$ & $0.5-1.5 \times 10^{7}$ & $0.5-2.5$ & $0.2-1.8$ \\
\hline \multirow[t]{2}{*}{$\begin{array}{l}\text { A. } \\
\text { formosa }\end{array}$} & $\begin{array}{l}\text { Present } \\
\text { study }\end{array}$ & 2000 & $\begin{array}{l}\text { Kavaratti, } \\
\text { Lakshadweep } \\
\text { Islands }\end{array}$ & $\begin{array}{l}2.9 \times 10^{6} \pm \\
1.45 \times 10^{6}\end{array}$ & 2.7 & 0.5 \\
\hline & $\begin{array}{l}\text { Jones RJ, } \\
1997 a\end{array}$ & 1994 & $\begin{array}{l}\text { Great Barrier } \\
\text { Reef, } \\
\text { Australia }\end{array}$ & $\begin{array}{l}\sim 1.8 \times 10^{5} \\
\text { polyp }^{-1}\end{array}$ & $4-5$ & nd \\
\hline
\end{tabular}

$\mathrm{Nd}=$ not done 


\section{Legends to the Figures}

Fig. 1. Sampling site, the Kavaratti island (a) of the Lakshadweep group of islands in the Arabian Sea (b).

Fig. 2. Chlorophyll a (a), Chlorophyll $\underline{\mathrm{c}}$ (b), chlorophyll $\underline{\mathrm{a}} / \mathrm{chl} \underline{\mathrm{c}}$, (c), phaeopigment (d), zooxanthellae density (e), mitotic index (f), RNA/DNA ratio (g) and total protein (h) in healthy (dark shaded), semi-bleached (light-shaded) and bleached (unshaded) colonies of Porites lutea and Acropora formosa.

Fig. 3 Percentage reduction in various parameters in semi-bleached and bleached corals of $P$.lutea and $A$. formosa. The values in healthy-looking corals were assumed to be $100 \%$. Phaeo=phaeopigments, $Z D=$ zooxanthellar density

Fig. 4. Principal component analysis (PCA) of the eight parameters pooled from all the three conditions of health in a) $P$. lutea and b) $A$. formosa. PCA generated two principal components, Factor 1 and Factor 2. In P. lutea, zooxanthellae density (ZD), chl a, chl c, and rna/ dna ratio were under Factor 1 that contributed $52 \%$ of the variance, whereas protein contributed $19 \%$ of the variance under Factor 2. In A.formosa, chl a, chl c, chl a/c and phaeopigments contributed to 52 $\%$ variance under Factor 1, whereas under Factor 2, mitotic index (MI) contributed to $16 \%$ of the variance. Together they explained about 71 and $72 \%$ of the variation in these two species.

Fig. 5. Protein profiles in healthy $(H)$, semi-bleached $(S)$ and bleached $(B)$ samples of a) Porites lutea and b) Acropora formosa. M indicates standard protein markers.

Fig. 6. (a) Lipofuscin granules in P.lutea appear golden colored (arrow) under bright field, (b) stained with Rhodamine B and observed under bright field, (c) appear silver gray in color under an epifluorescence microscope when stained 
with Rhodamine B and (d) appear black when observed under bright field after staining with Sudan black. Note the deteriorated and highly vacuolated cytoplasmic content of the host tissue.

Fig.7. (a) Sections of healthy tissue showing compact arrangements of epidermis layer (b) semi-bleached tissue showing swelling of mesoglea and large vacuoles and (c) bleached tissue of $P$. lutea showing large vacuoles and degenerated tissue. (a1, b1 and c1) sections of healthy, semi-bleached and bleached tissue of A. formosa. The abbreviations are; Ep - Epidermis, En - Endodermis, M Mesoglea Vac - Vacuoles, Zx - Zooxanthellae 


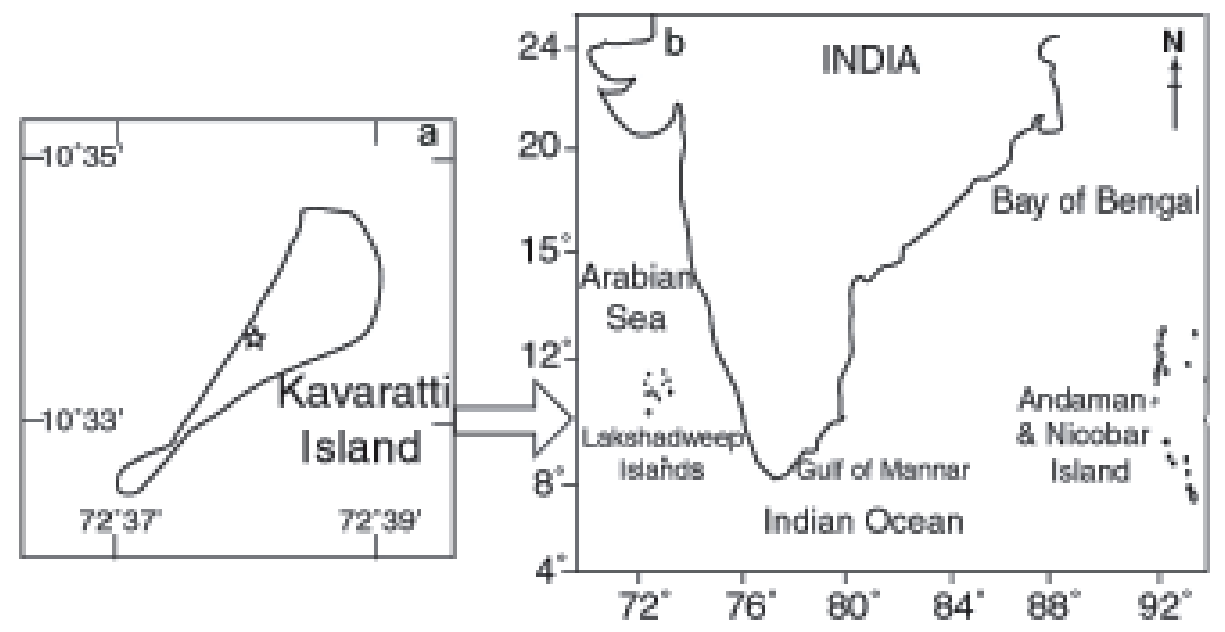

Fig. 1. Sampling site, the Kavaratti island (a) of the Lakshadweep group of islands in the Arabian Sea (b). 

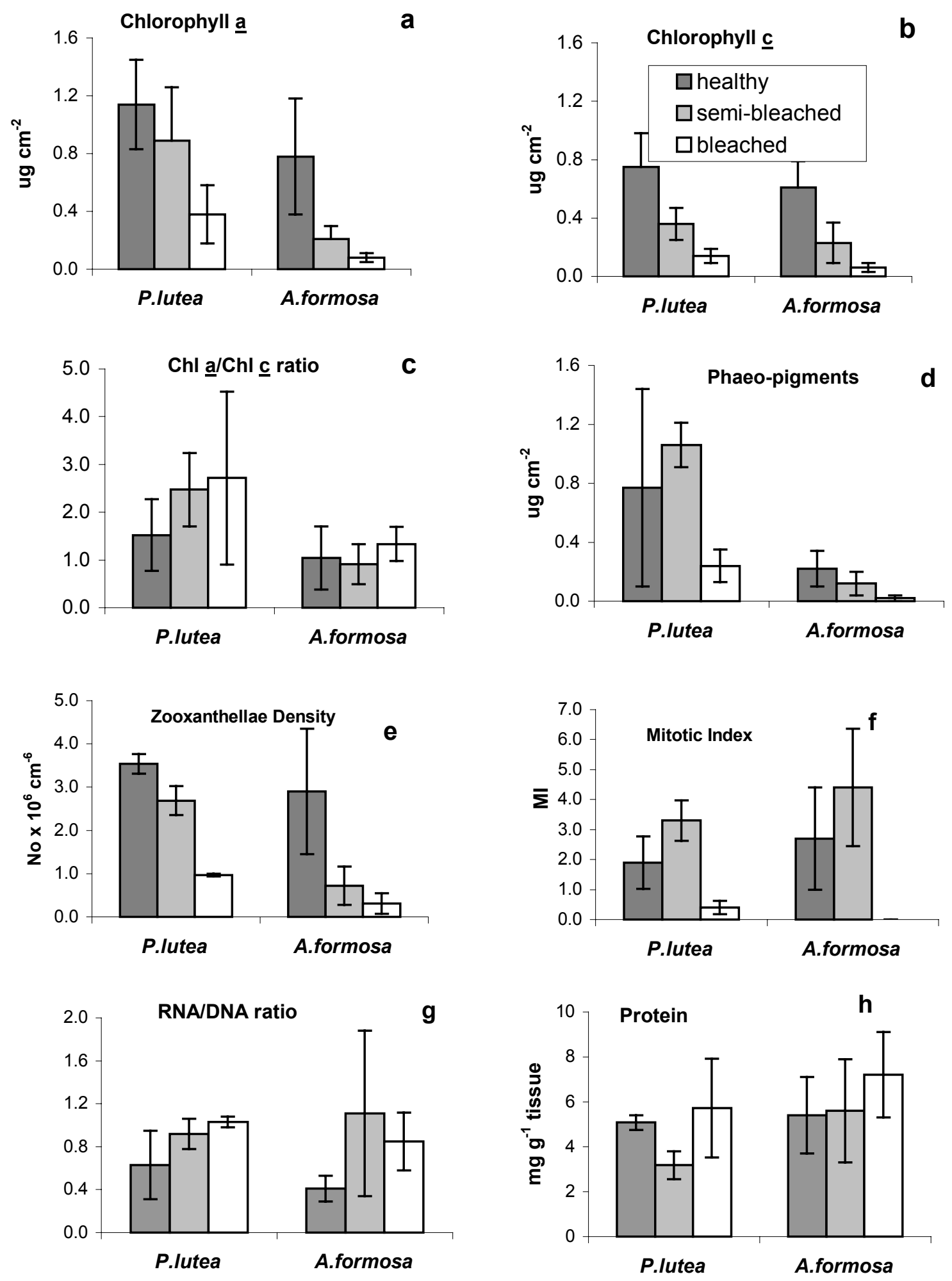

Fig. 2. Chlorophyll a (a), Chlorophyll $\underline{\mathrm{c}}$ (b), chlorophyll $\underline{\mathrm{a}}$ /chl $\underline{\mathrm{c}},(\mathrm{c})$, phaeopigment (d), zooxanthellae density (e), mitotic index (f), RNA/DNA ratio $(\mathrm{g})$ and total protein $(\mathrm{h})$ in healthy (dark shaded), semi-bleached (light-shaded) and bleached (unshaded) colonies of Porites lutea and Acropora formosa. 


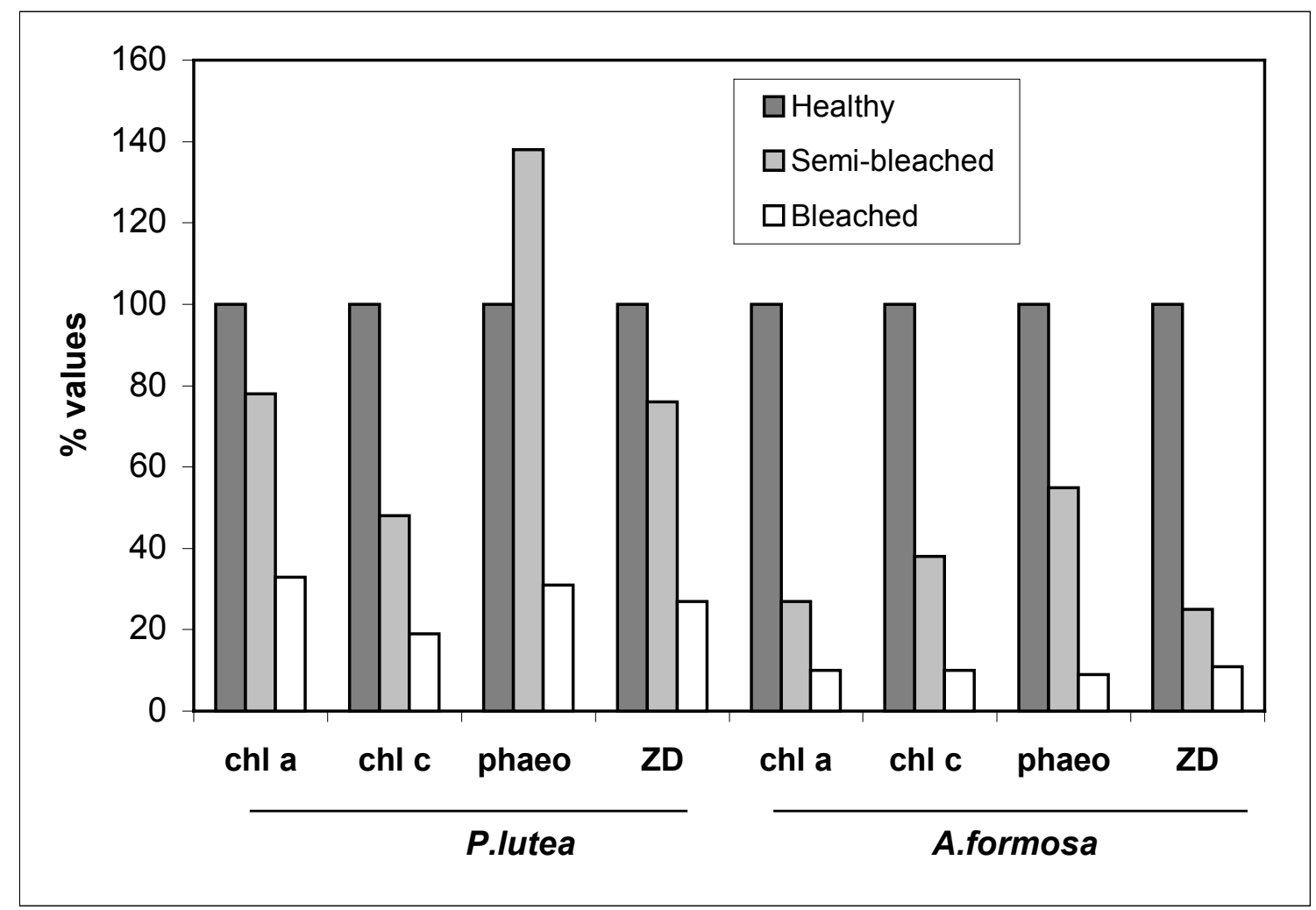

Fig. 3 Percentage reduction in various parameters in semi-bleached and bleached corals of P.lutea and $A$. formosa. The values in healthy-looking corals were assumed to be $100 \%$. Phaeo=phaeopigments, $Z D=$ zooxanthellar density 

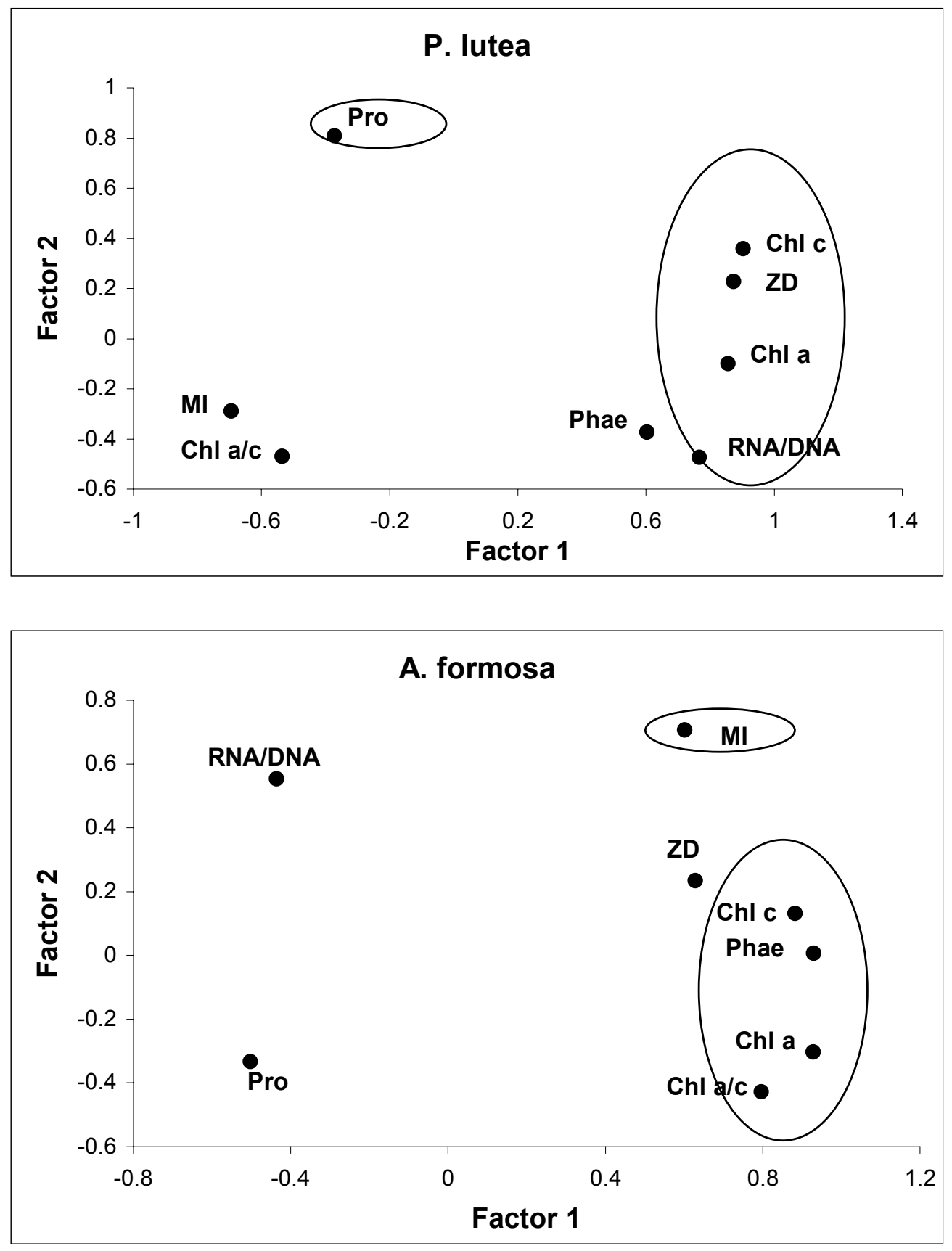

Fig. 4. Principal component analysis (PCA) of the eight parameters pooled from all the three conditions of health in a) $P$. lutea and b) $A$. formosa. PCA generated two principal components, Factor 1 and Factor 2. In $P$. lutea, zooxanthellae density (ZD), chl a, chl c, and rna/ dna ratio were under Factor 1 that contributed $52 \%$ of the variance, whereas protein contributed $19 \%$ of the variance under Factor 2. In A.formosa, chl a, chl c, chl a/c and phaeopigments contributed to 52 $\%$ variance under Factor 1, whereas under Factor 2, mitotic index (MI) contributed to $16 \%$ of the variance. Together they explained about 71 and $72 \%$ of the variation in these two species. 

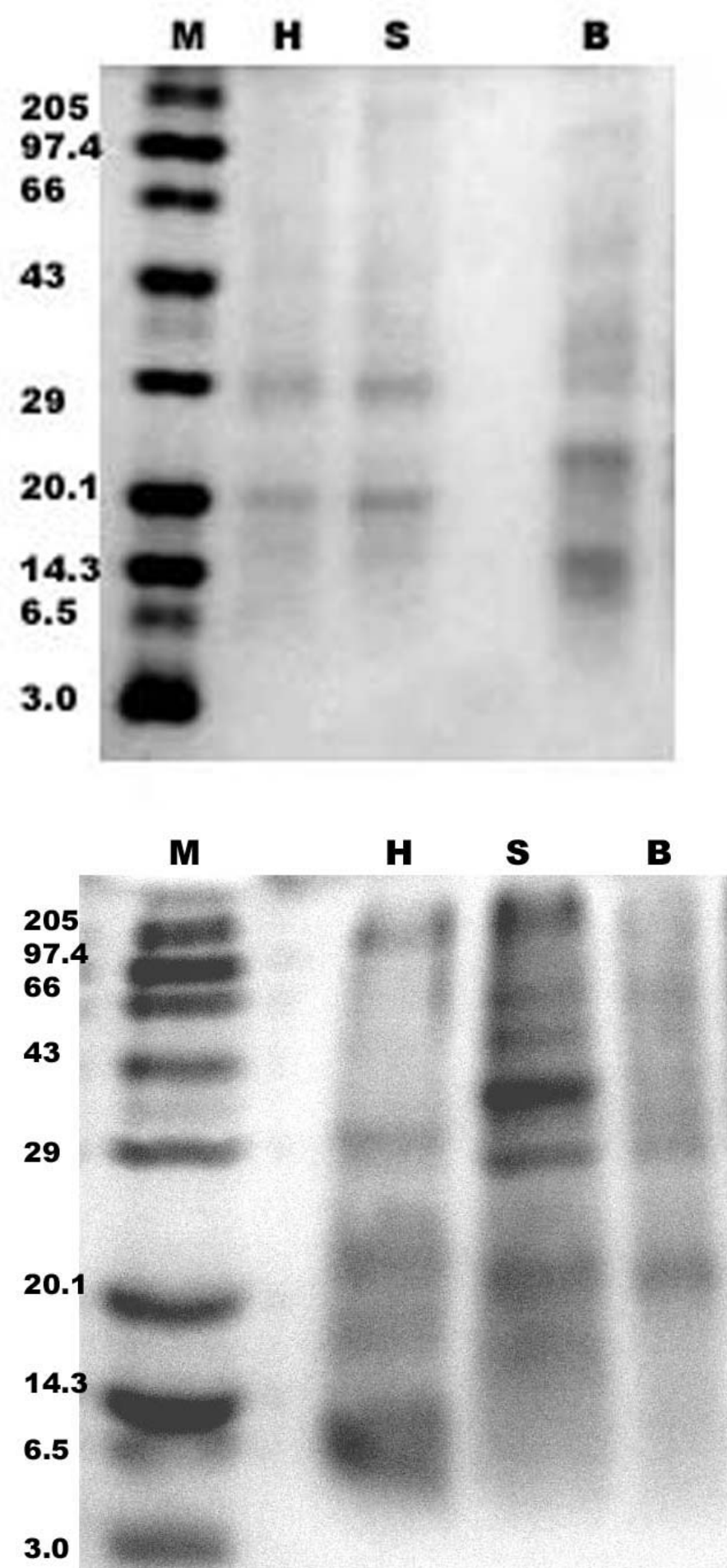

Fig. 5. Protein profiles in healthy $(H)$, semi-bleached $(S)$ and bleached $(B)$ samples of a) Porites lutea and b) Acropora formosa. M indicates standard protein markers. 

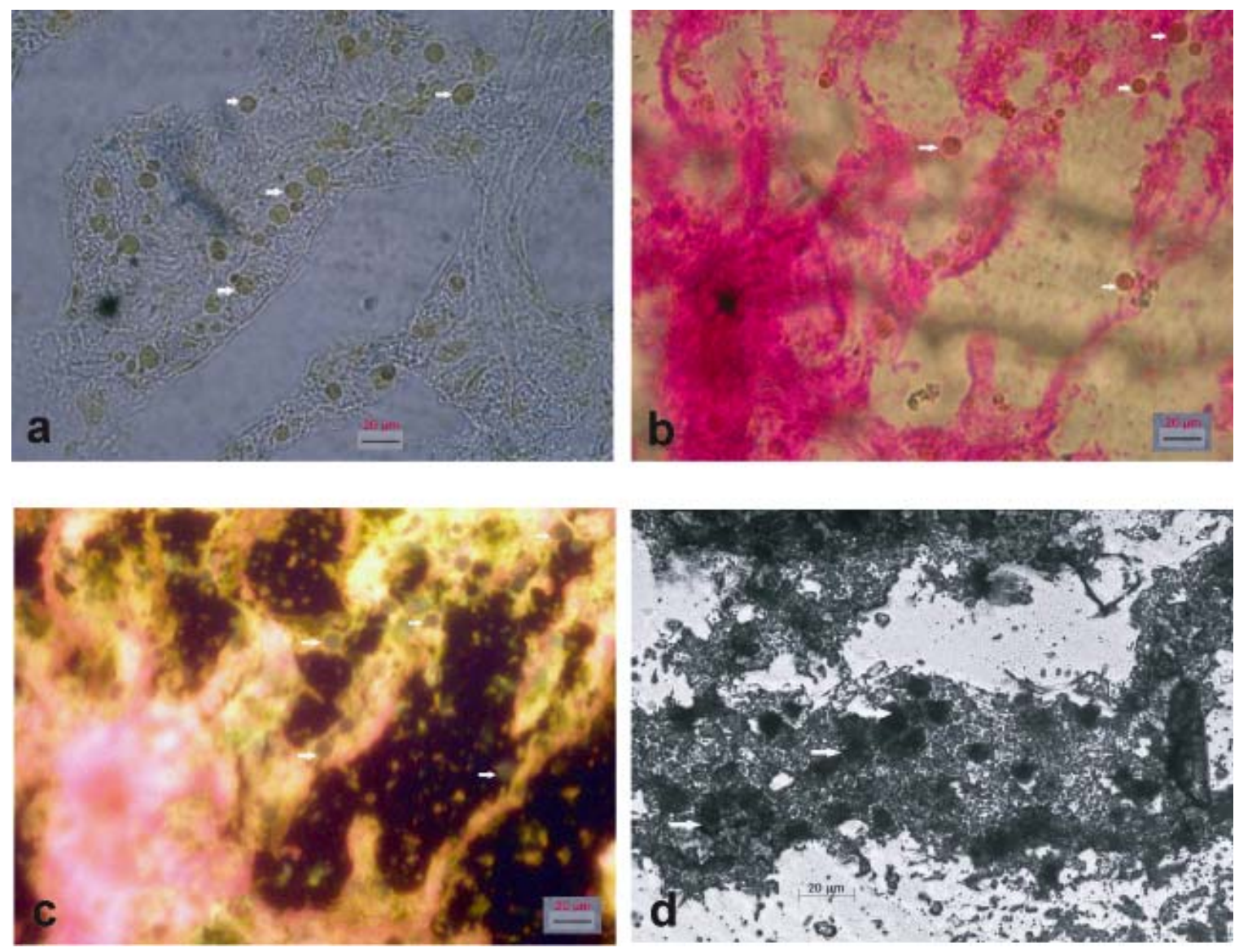

Fig. 6. (a) Lipofuscin granules in P.lutea appear golden colored (arrow) under bright field, (b) stained with Rhodamine B and observed under bright field, (c) appear silver gray in color under an epifluorescence microscope when stained with Rhodamine B and (d) appear black when observed under bright field after staining with Sudan black. Note the deteriorated and highly vacuolated cytoplasmic content of the host tissue. 

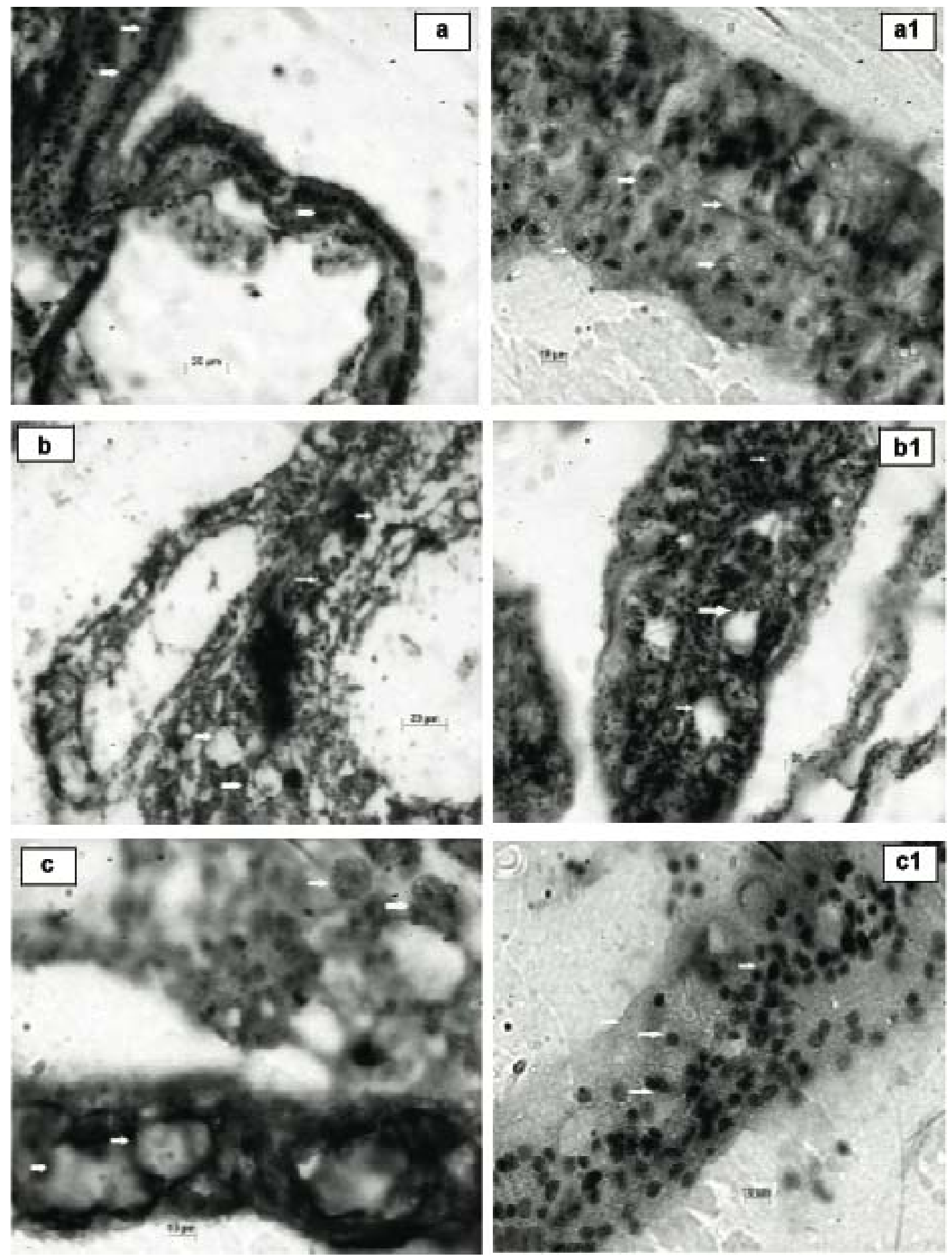

Fig.7. (a) Sections of healthy tissue showing compact arrangements of epidermis layer (b) semi-bleached tissue showing swelling of mesoglea and large vacuoles and (c) bleached tissue of $P$. lutea showing large vacuoles and degenerated tissue. (a1, b1 and c1) sections of healthy, semi-bleached and bleached tissue of A. formosa. The abbreviations are; Ep - Epidermis, En - Endodermis, M Mesoglea Vac - Vacuoles, Zx - Zooxanthellae 